\title{
Identification of genetic soil types based on remote sensing data
}

Ekaterina Kulik, Arslanbek Bajshuakov

Siberian State University of Geosystems and Technologies, Photogrammetry and Remote Sensing Department, 10 Plakhotnogo street, 630108, Novosibirsk, Russia

\begin{abstract}
At the present stage of social development traditional contact methods of studying the territory features are inferior to other, less costly and more profitable technologies. Such technology is automation of space imagery information interpretation. It allows to minimize scope of field works and it is economically and managerially profitable method of territory analysis. So, in the work the methods of digital analysis and automatic Earth remote data sensing interpretation are used for identification of genetic soil types. During the research conditions of the land has been determined by calculation and index images analysis. The application of interpretational signs had allowed to identify genetic soil types. The methodology and the results of the analysis can serve as a basis for solving the problems of updating soil maps.
\end{abstract}

In the tasks of monitoring natural resources, it is very important to identify the characteristics of soils. Soil fertility assessment is considered an integral part of agricultural monitoring. The analysis of the soil condition makes it possible to identify degraded and disrupted lands in order to further develop measures for soil recovery. By analyzing the remote sensing data (RSD) of the Earth, it becomes possible to monitor soil fertility, create and update soil maps. Their use helps agricultural producers to carry out soil suitability classification and soil rating. The purpose of this study is the application of methods for automating the RSD analysis for finding-out of genetic soil types.

To accomplish purpose, there were formulated tasks aimed at in-depth geographical exploration of territory. The tasks are to determine of vegetation and soil conditions using the SAVI soil index and to map soil types identified by interpretational signs.

As source data work uses multispectral image received by SPOT- 6 satellite system. The SPOT-6 spacecraft engineered by Airbus Deference and Space (France). The acquisition is performed from the orbit that has an altitude of $694 \mathrm{~km}$. Each SPOT-6 scene is about 60 kilometers long and 60 kilometers wide. Spectral bands of imaging instruments are presented by optical wave channels in the range from 0.45 to $0.69 \mu \mathrm{m}$ as well as nearinfrared channel in the range from 0.76 to $0.89 \mu \mathrm{m}$. For panchromatic acquisition the range from 0.45 to $0.75 \mu \mathrm{m}$ was used [1]. The soil map from 1985 was used as additional thematic information. The study area is located in the northern part of Dovolensky district of Novosibirsk region on the lands of the Utyanka municipality. These lands have been in agricultural use for a considerable number of years.

The topography of the study area is slightly dissected wavy plain with low paralleloriented from southwest to northeast hill chains up to 15 meters. The hill chains are occupied by chernozem soils [2]. The valleys between hill chains are occupied by wetlands and lakes where boggy and peat-boggy soils are spread. Most of the study area is occupied by forest-steppe plains, which are dominated by solonetzes. Parent materials are loam and sandy loam.

The content in plants is rather heterogeneous. There are grassland steppes and steeped grasslands on solonetzes. In depressions occupied by aspen-birch outlier forest there are 
solods. On lakeland terraces there are solonchaks with sparse vegetation represented by specific halophytic species.

In relatively small areas fitted within the individual satellite high-resolution imageries it is possible to conduct research to identify seasonal and/or multi-year local changes in the characteristics of geosystems. For soil types interpretation it is advisable to use images of the spring and autumn period, when the vegetation is more sparse or absent at all. The most reliable genetic soil types identification is achieved where feasible to analyze such direct interpretational signs as spectral brightness, color, background, size, shape, structure, texture, and pattern. Indirect interpretational signs of soil types are vegetation and relief features. Also it may be considered the use of such auxiliary material as soil, topographic and geobotanical maps if the high recognizing reliability of objects types from their images is aimed [3].

For identification of areas with bare ground and vegetation the SAVI (Soil Adjusted Vegetation Index) index image calculation method was used [4]. The SAVI index is calculated according to formula 1 using $\mathrm{L}$ correction factor. It is introduced to bring the index with sparse vegetation to the NDVI range:

$$
\mathrm{SAVI}=\frac{(\mathrm{NIR}-\mathrm{Red})}{(\mathrm{NIR}+\mathrm{Red}+\mathrm{L})} *(1+\mathrm{L})
$$

The SAVI soil index was calculated using the ScanEx Image Processor software package, in which a value greater than 0.5 is set for the $\mathrm{L}$ correction factor if the vegetation cover is not significantly presented on the ground [5]. The most convenient way to work with these indices is to use images before the tillering period of agricultural vegetation, during the period of early germination and after harvesting. After setting the parameters in the SAVI soil index operation in the ScanEx Image Processor software package, a grayscale image is produced in the output. The SAVI color palette is used to color the result, similarly to the NDVI. According to the given color scheme, the resulting index image shows the condition of the vegetation.

The calculation of the vegetation soil index SAVI resulted in the identification of areas with bare soils which are characteristic of arable land located on chernozem soils. As the image of the autumn period was used, a visual assessment confirmed that crops had been harvested. Image analysis had shown that most of the area is occupied by sparse vegetation.

There is a correlation directly between the results obtained on the basis of the analysis of the index image presented in Figure 1 and the soil types of the local territory, since the boundaries of the areas with identified soil types are similar to the contour part of the retrospective soil maps. It confirms the eligibility of use vegetation indicators (the state and characteristics of the vegetation are determined by the values of vegetation indices) in this type of interpretation of remote sensing data.

The lake shoreline corresponds to boggy and peat-boggy soil types. The boundaries of areas with weak and sparse vegetation are similar to the boundaries of areas with meadow and solonetz soils. Areas with dense vegetation are characterized by outlier forests under which solod soils are formed. So identification of genetic soil types and delineation of their extent can be performed using automated analysis of vegetation index images, where vegetation indicators act as reliable indirect interpretational signs. 


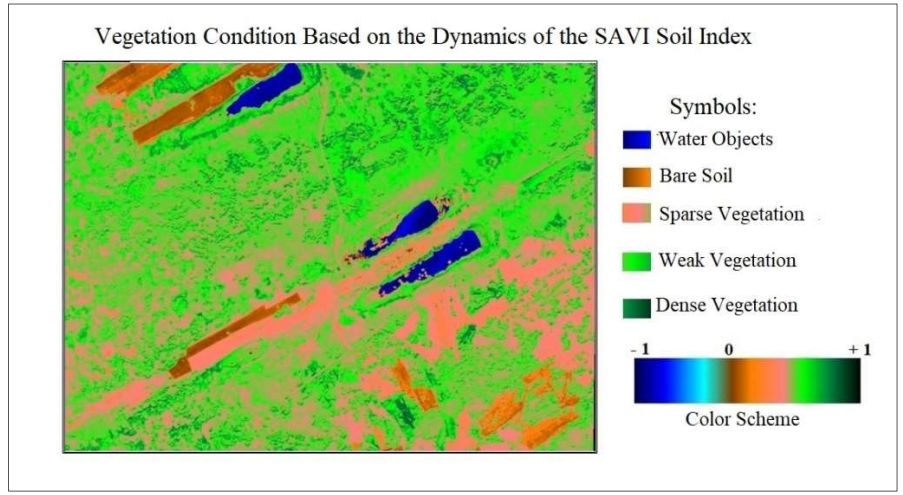

Fig. 1. Index Image of SAVI

Using indirect interpretational signs, vegetation and topography indicators as well as index image and 1985 soil map data, a soil type scheme including eight genetic types was produced in the ArcGIS software package. The following soil types have been identified:

- chernozems,

- meadows,

- boggies,

- meadow-chernozemics,

- chernozem-meadows,

- solonetzes,

- solonchaks,

- solods (Figure 2, Table 1).

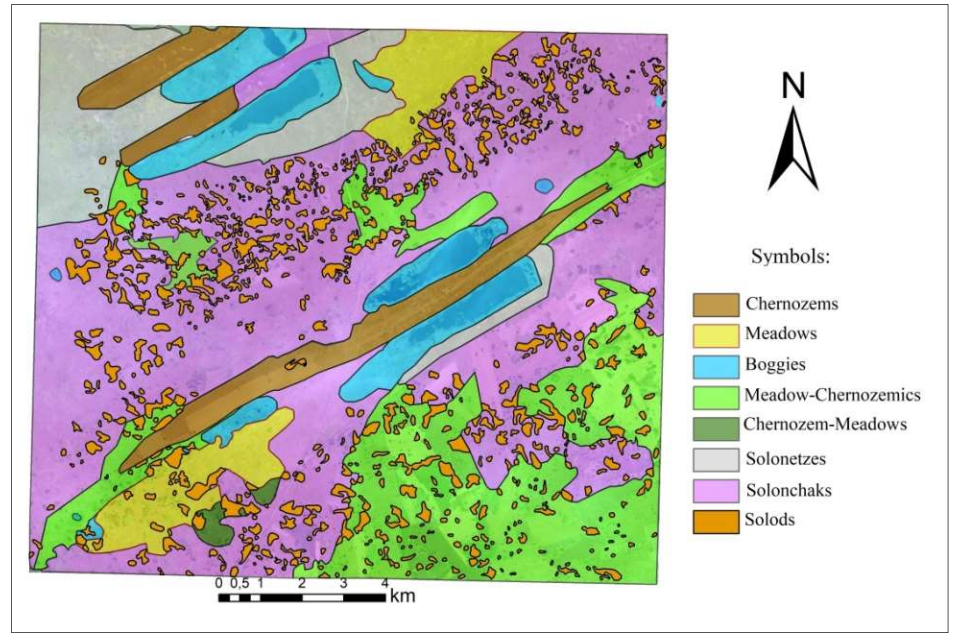

Fig. 2. Scheme of Soil Types 
Table 1. Soil types

\begin{tabular}{|c|c|}
\hline Name in English & Name in the WRB system \\
\hline Chernozems & Chernozems \\
\hline Boggies & Fibric Histosols \\
\hline Meadows & Eutric Vertisols \\
\hline Meadow-chernozemics & Luvic Chernozems \\
\hline Chernozem-meadows & Haplic Arenosols \\
\hline Solonetzes & Solonetz \\
\hline Solonchaks & Solonchaks \\
\hline Solods & Haplic Gleysols/ Solodic Planosols \\
\hline
\end{tabular}

The chernozem soils are formed in areas with a flat surface, occupied by crops with a high accumulation of organic matter (humus). Black tone, parallel-striped image texture and color are used for interpretation. The chernozem-meadow soils can be formed under croplands. Such soils are created under a highly productive herbaceous cover, and have a higher humus proportion than chernozem soils.

The meadow soils are generally formed under herbaceous vegetation, which serves as an indicator for the identification of this soil type. The interpretational signs are homogeneous structure and color.

The solonetzes are formed on saline rocks on the plains and in the lowlands. Vegetation on solonetz soils is represented by specific species with deep root systems such as artemisia (Artemísia), fescue (Festuca valesiaca) and Stipa. The heterogeneous grain structure, spotty texture and different shades of color have become interpretational signs for the identification of solonetz soils. However, the identification of solonetz soils was accompanied by the availability of data from a retrospective soil map.

As distinct from the solonetzes, solonchaks contain water-soluble salts on the surface. There are easily recognizable visually on the images, having a light tone and homogeneous structure at interpretation. The vegetation on solonchaks is sparse and represented by specific halophyte species.

Solod soils do not occupy continuous vast areas, but they are usually found as local areas within the steppe and forest-steppe zones. These soils are formed in small depressions under the aspen and birch outlier forests.

The boggy and peat-boggy soils are found in depressions on the site of lake and waterlogged basins.

As a result of genetic soil types identification, a soil type scheme was made using the high-resolution satellite image and the soil map of 1985. In creating this scheme, the relationships between the soil types and the indicators for their identification were studied.

Calculation of various index images is a very flexible, quite popular and often universal method of multispectral satellite data analysis to obtain information about the characteristics of vegetation and soil cover [6]. As a result of research on this subject the authors studied geographical features of the area of interest. There was applied methods of digital image processing such as calculating the SAVI index and using interpretational signs for the of soil types mapping. The represented results with identified soil genetic types based on remote sensing data will allow agricultural enterprises to outline rational methods of soil treatment.

This study was conducted with the information support of private Limited Liability Company Engineering and Technology Center "SCANEX" (with the supply of satellite images from the archive). It is based on the validity of the right to receive information support and images by the winners of the All-Russian Student Olympiad on Thematic Earth Remote Sensing Data Interpretation held at the Reshetnev Siberian State University of Science and Technology in August 2017. 
Digital satellite image processing was carried out using ScanEx Image Processor software package. The results were processed in ArcGIS software package.

\section{References}

1. E. Kulik, A. Bayshuakov, Monitoring of the agricultural crops states at different vegetation stages using remote sensing data, Regional Problems of Earth Remote Sensing: Proceedings of the VII International Scientific Conference, 29 September - 2 October 2020 , pp. 248 - 250, Krasnoyarsk, Russia (2020)

2. A. Bayshuakov, Analysis of geographical features from satellite imagery for soil mapping purposes, Aktual'nye Napravleniya Geograficheskih Issledovanij v Kemerovskoj Oblasti i Drugih Regionah Rossii [Topical Areas of Geographical Research in the Kemerovo Region and Other Regions of Russia], 25-28 February 2021, pp. $84-88$, Kemerovo, Russia (2021)

3. A. Gordienko, The use of index imagery in detecting changes in multi-temporal satellite images, Interekspo GEO-Sibir' [Interexpo GEO-Siberia], 13 - 25 April 2015, 4, pp. 67 - 70, Novosibirsk, Russia (2015)

4. Soil Adjusted Vegetation Index // Index Database. URL: http://www.indexdatabase.de/db/i-single.php?id=87

5. N. Sokolova, D. Sokolov, The use of vegetation indexes to assess the soil-ecological condition of technogenic landscapes, Pochvy v Biosfere: Sbornik Materialov Nauchnoj Konferencii s Mezhdunarodnym Uchastiem, Posvyashchennoj 50-letiyu Instituta Pochvovedeniya i Agrohimii SO RAN [Soils in the Biosphere: Proceedings of the Scientific Conference with International Participation, Dedicated to the 50th Anniversary of the Institute of Soil Science and Agrochemistry SB RAS], 10 September - 14 October 2018, pp. 345 - 349, Tomsk, Russia (2018)

6. S. Drozdov, S. Sladkopevtsev, Distancionnye metody ocenki prirodnyh resursov (rel'ef i pochvy) [Remote sensing methods for natural resource assessment (landforms and soils)], 178 p., Moscow, Russia (2015) 